medRxiv preprint doi: https://doi.org/10.1101/2021.07.05.21259938; this version posted July 7, 2021. The copyright holder for this preprint (which was not certified by peer review) is the author/funder, who has granted medRxiv a license to display the preprint in perpetuity.

\title{
Derivation of anthropometric-based equations to predict lean body mass composition of cancer patients
}

Autumn B. Carey ${ }^{1}$, Ashley S. Felix ${ }^{1}$, Jared D. Huling ${ }^{2}$, James B. Odei ${ }^{3}$, Christopher C. Coss $^{4}$, Xia Ning ${ }^{5,6}$, and Macarius M. Donneyong ${ }^{7,8}$

${ }^{1}$ Division of Epidemiology, The Ohio State University College of Public Health, Columbus, $\mathrm{OH} 43210$

${ }^{2}$ Division of Biostatistics, University of Minnesota School of Public Health, Minneapolis, MN 55455

${ }^{3}$ Division of Biostatistics, The Ohio State University College of Public Health, Columbus, $\mathrm{OH} 43210$

${ }^{4}$ Department of Pharmaceutics and Pharmaceutical Chemistry, The Ohio State University College of Pharmacy, Columbus, OH 43210

${ }^{5}$ Department of Biomedical Informatics, The Ohio State University College of Medicine, Columbus, $\mathrm{OH} 43210$

${ }^{6}$ Department of Computer Science and Engineering, The Ohio State University College of Engineering, Columbus, $\mathrm{OH} 43210$

${ }^{7}$ Department of Pharmacy Practice and Science, The Ohio State University College of Pharmacy, Columbus, OH 43210

${ }^{8}$ Division of Health Services Management and Policy, The Ohio State University College of Public Health, Columbus, OH 43210

\section{CORRESPONDING AUTHOR:}

Macarius M. Donneyong, PhD, MPH

Riffe Building, 400

500 W. $12^{\text {th }}$ Ave.

Columbus, $\mathrm{OH} 43210$

donneyong.1@osu.edu

Disclosure: The authors do not have any disclousures relavent to this study. 
medRxiv preprint doi: https://doi.org/10.1101/2021.07.05.21259938; this version posted July 7, 2021. The copyright holder for this preprint (which was not certified by peer review) is the author/funder, who has granted medRxiv a license to display the preprint in perpetuity.

All rights reserved. No reuse allowed without permission.

\begin{abstract}
Background: Lean body mass (LBM) composition of cancer patients is a predictor of chemotherapy-related adverse events and overall cancer survival. However, clinicians lack validated algorithms that can be applied to measure the LBM of cancer patients to facilitate accurate chemotherapy dosing. Our goal was to develop LBM predictive equations using routinely measured anthropometric measures among cancer patients.

Methods: We leveraged the 1999-2006 National Health and Nutrition Examination Survey (NHANES) data cycles containing information on self-reported cancer diagnosis, LBM measures based on dual-energy $x$-ray absorptiometry (DXA) and several anthropometric and demographic factors. We restricted our analysis to participants who had been diagnosed with cancer at the time of surveys. The data was randomly split to $75 \%: 25 \%$ to train and test predictive models. Least absolute shrinkage and selection operator (LASSO) models were used to predict LBM based on anthropometric and demographic factors, overall and separately among sex and sex-by-race/ethnic subgroups. LBM measured directly with DXA served as the gold standard for assessing the predictive abilities (correlations $\left[\mathrm{R}^{2}\right.$ ] and the Root Mean Square Error [RMSE]) of the derived LBMalgorithms. We further compared the correlations between both DXA-based LBM and predicted LBM and urine creatinine levels, a known biomarker of muscle mass.
\end{abstract}

Results: We identified 1,777 cancer patients with a median age of 71 (interquartile range [IQR]: 60-80) years. The most parsimonious model comprised of height and weight, which accurately predicted LBM overall $\left(R^{2}=0.86, R M S E=2.26\right)$. The predictive abilities of these models varied across sex-by-race/ethnic groups. The magnitude of correlations between derived LBM-algorithm and urine creatinine levels were larger compared to those measured between DXA-based LBM and urine creatinine levels $\left(R^{2}=0.30\right.$ vs. $R^{2}=0.17$ )

Conclusions: We successfully developed a simple sex-specific and sex-by-race/ethnicityspecific models to accurately predict the LBM of cancer patients by using only height and weight. The simplicity and high accuracy of these models make them inexpensive alternatives to measuring the LBM of cancer patients. Data on the LBM of cancer patients 32 could help guide optimal chemotherapy dose selection among cancer patients. 
medRxiv preprint doi: https://doi.org/10.1101/2021.07.05.21259938; this version posted July 7, 2021. The copyright holder for this preprint (which was not certified by peer review) is the author/funder, who has granted medRxiv a license to display the preprint in perpetuity.

\section{INTRODUCTION}

In 2020, approximately 1.8 million cancers are expected to be diagnosed in the United States, with approximately 0.6 million cancer-related deaths ${ }^{1}$. Cancer is the second leading cause of death with a five-year mortality rate of $34.1 \%{ }^{1,2}$. Notwithstanding this high mortality burden, advances in treatment underlie significant declines in cancer mortality over the past 20 years, with rates dropping from 209.9 per 100,000 people in 1995 to 158.7 per 100,000 people in $2015^{2}$. Chemotherapy has been shown to improve cancer survival, especially for advanced stage cancers ${ }^{3,4}$. However, this benefit could be offset by the negative impact of chemotherapy-induced adverse events and chemotoxicity effects, such as hair loss, nausea, vomiting, or death. These adverse effects can lead to treatment cycle interruption or discontinuation, both of which contribute to poor cancer outcomes and higher mortality ${ }^{5}$.

Chemotoxicity is caused by the excretion or poor metabolism of chemotherapeutic drugs, resulting in higher than expected circulating levels of the drug 6,7 . Known risk factors for poor chemotherapeutic drug metabolism are determinded by the pharmacokinetic properties of the chemotherapeutic drug, but often include low lean muscle mass ${ }^{6}$. Prado et al (2007) found that a cut point of $20 \mathrm{mg} 5$-fluorouracil per kilogram of total lean body mass (LBM) is a threshold for developing toxicity ( $p$ value $<0.01)^{6}$. LBM is comprised of metabolic tissue (liver and kidneys), skeletal muscle, intracellular water, extracellular water, and bone ${ }^{8}$. Thus, research continues to emphasize the value of measuring body composition to normalize drug dosing, optimize outcomes, and mitigate chemotoxicty 6, 9-12.

In clinical practice, chemotherapy dosing is based on body weight, body mass index (BMI) or body surface area (BSA). This practice may pose challenges to measuring the optimal dose of chemotherapy for individual patients. BMI is limited as it does not capture a valid measure of body composition phenotypes (i.e. lean muscle mass, lean muscle mass percentage, fat mass, and fat mass percentage) and does not readily explain inter-patient variability in drug clearance inter-patient variability despite its use in many epidemiological studies assessing chemotoxicity risk and cancer outcomes ${ }^{13}, 14$.

62 Chemotherapy dosing based on BSA is a common clinical practice in oncologic settings. 
medRxiv preprint doi: https://doi.org/10.1101/2021.07.05.21259938; this version posted July 7, 2021. The copyright holder for this preprint (which was not certified by peer review) is the author/funder, who has granted medRxiv a license to display the preprint in perpetuity.

All rights reserved. No reuse allowed without permission.

63 However, variation in the pharmacokinetics of most chemotherapies has failed to be standardized by BSA-based dosing ${ }^{15-17}$.

Dual-energy x-ray absorptiometry

(DXA) and computed tomography (CT) are imaging tools used to accurately calculate body composition among cancer patients.

67 However, CT scans are expensive and emit a high dose of ionizing radiation ${ }^{18}$. DXA is relatively inexpensive and emits low amounts of radiation, but whole body DXA examination equipment is not typically accessible in an oncologic clinic setting ${ }^{18,19}$. Due to these limitations, anthropometric measures in conjunction with age, sex, weight, and height are needed to precisely estimate body composition for chemotoxicity risk stratification 13,20 .

Several studies have shown that LBM can be estimated accurately by using equations that comprise of simple anthropometric measures ${ }^{21-24}$. However, none of these studies published data the application of anthropometric-based equations to measure LBM specifically among cancer patients. Therefore, our primary objective was to develop anthropometric-based models to accurately predict LBM among cancer patients.

\section{METHODS}

\section{Study Population}

Participants were selected from the National Health and Nutrition Survey (NHANES), a series of cross-sectional surveys designed to assess the health and nutritional status of adults and children in the United States conducted by the Centers for

83 Disease Control and Prevention ${ }^{25}$. Because NHANES is a publically available dataset,

84 The Ohio State University IRB did not constitute the project to require human subjects review. NHANES participants were selected using complex, stratified, multi-staged 86 probability sampling to be representative of the US civilian non-institutionalized 87 population ${ }^{26-28}$. All survey cycles between 1999 and 2014 were utilized. Figure 1 depicts 88 sample selection for the development of the final training, testing and validation of models.

89 Inclusion/Exclusion criteria

90 We included participants with a self-reported cancer diagnosis aged $\geq 18$ years old.

91 Pregnant women were excluded ${ }^{29}$.

92 Outcomes

93 Dual-Energy X-Ray Absorptiometry Measurements 
medRxiv preprint doi: https://doi.org/10.1101/2021.07.05.21259938; this version posted July 7, 2021. The copyright holder for this preprint (which was not certified by peer review) is the author/funder, who has granted medRxiv a license to display the preprint in perpetuity.

All rights reserved. No reuse allowed without permission.

Whole body DXA scans were used to measure LBM, fat mass, and fat mass percent of NHANES participants. A Hologic QDR 4500A fan-beam densitometer within the NHANES Mobile Examination Centers was used to measure body composition ${ }^{30-32}$.

97 Details of the body composition measurement and exclusion of participants have been 98 previously published ${ }^{31}$. Outliers at the individual level were coded as missing by NHANES staff prior to completing statistical analysis ${ }^{32}$.

100 Predictors

\section{Anthropometric Measurements}

We focused on the following anthropometric measures that have been assessed

103 as predictors of LBM in the published data 21-24: height (cm), weight $(\mathrm{kg})$, arm 104 circumference $(\mathrm{cm})$, abdominal circumference $(\mathrm{cm})$, calf circumference $(\mathrm{cm})$, thigh 105 circumference $(\mathrm{cm})$, tricep skinfold $(\mathrm{cm})$, and subscapular skinfold (cm). These 106 anthropometric measures were collected in the Mobile Examination Center by two trained 107 health technicians, an examiner and recorder, per NHANES standardized procedures and 108 equipment ${ }^{33}$. For the modeling procedures, all anthropometric variables were modeled as 109 continuous variables, and tricep and subscapular skinfold measures were converted from 110 units of millimeters to centimeters.

\section{Other measures}

112 Demographic factors examined in this study are age, time between cancer 113 diagnosis and NHANES screening age (years), race (Black Non-Hispanic, Mexican 114 American and Hispanic, White Non-Hispanic and other (which includes multiracial), and 115 sex (male and female). Age was top coded at 80 years old in NHANES cycles 1999-2006 116 and 85 years old in NHANES cycles 2007-2014 to maintain confidentiality. Thus, for this 117 analysis, all individuals over the age of 80 were top coded at 80 to be uniform across all 118 survey cycles. Additionally, age of cancer diagnosis or most recent cancer diagnosis,if 119 multiple diagnoses were reported, were examined to calculate the time between cancer 120 diagnoses and LBM measurement. In addition to these demographic factors, we selected 121 urine creatinine levels as a potential biomarker for muscle ${ }^{34,35}$. Urine creatinine levels 122 were measured via 24-hour urine samples collected within 2 weeks of DXA 123 measurements and analyzed by NHANES staff ${ }^{36}$. 
medRxiv preprint doi: https://doi.org/10.1101/2021.07.05.21259938; this version posted July 7, 2021. The copyright holder for this preprint (which was not certified by peer review) is the author/funder, who has granted medRxiv a license to display the preprint in perpetuity.

All rights reserved. No reuse allowed without permission.

125 The complex sampling design of NHANES was accounted for by proper use of the

126 sample and cycle weights in all analysis ${ }^{37}$. We implemented the analysis described

127 below with SAS 9.4 and R 1.2.1335.

128 Descriptive analysis

Proportions and means were used to describe categorical and continuous

130 variables, respectively, overall, by sex, and by NHANES data cycles (with and without

131 whole-body DXA measurements).

132 Missing Data

133 Greater than $10 \%$ of participants included in our analytic sample were missing data

134 for BMI $\left(\mathrm{kg} / \mathrm{m}^{2}\right)$, BSA $\left(\mathrm{m}^{2}\right)$, all eight anthropometric measures, creatinine $(\mathrm{mg} / \mathrm{dL})$, and 135 DXA measures. We applied Multivariate Imputation by Chained Equations (MICE) 136 models $^{38}$ to impute all missing values of predictors. MICE requires missing data models 137 to perform the imputation, for which flexible random forest models were used due to their 138 favorable performance ${ }^{39}$. To obtain valid estimates that take into account the uncertainty 139 in imputation, we construced twenty-five imputed datasets were constructed. NHANES 140 had already imputed missing DXA values prior to making data available to researchers 141 by using multiple-imputation methodology by the National Center for Health Statistics $142(\mathrm{NCHS})^{32}$. This missing data imputation was based on a sequential regression 143 multivariate imputation methodology to reflect smaller standard errors, narrower 144 confidence intervals, and falsely failing to reject null hypotheses that are often reflected 145 when utilizing single imputation methodsDXA technical doc ${ }^{32}$.

146 Algorithm development

147 We implemented five different models based on a combination of anthropometric 148 and demographic factors among the overall sample: 1) Model 1: height (cm) and weight 149 (kg) only; 2) Model 2: Model 1 plus age, time between cancer diagnosis and LBM 150 measurement date, sex, race/ethnicity; 3) Model 3: Model 2 plus interaction terms 151 between anthropometric predictors (height $(\mathrm{cm})$ and weight $(\mathrm{kg})$ ) and sex and age; 4) 152 Model 4: Model 3 plus additional interaction terms between anthropometric variables and 153 race/ethnicity; 5) Model 5: Model 4 plus all pairwise interactions between anthropometric 154 variables, age, time between cancer diagnosis and LBM measurement, sex, and 155 race/ethinicity. 
medRxiv preprint doi: https://doi.org/10.1101/2021.07.05.21259938; this version posted July 7, 2021. The copyright holder for this preprint (which was not certified by peer review) is the author/funder, who has granted medRxiv a license to display the preprint in perpetuity.

All rights reserved. No reuse allowed without permission.

Sex specific models were generated as follows: 1) Model 1: height (cm) and weight (kg) only; 2) Model 2: Model 1 plus age, time between cancer diagnosis and LBM measurement date, and race/ethnicity; 3) Model 3: Model 2 plus interaction terms between anthropometric predictors (height $(\mathrm{cm})$ and weight $(\mathrm{kg})$ ) and age; 4) Model 4: Model 3 plus additional interaction terms between anthropometric variables and race/ethnicity; 5) Model 5: Model 4 plus all pairwise interactions between anthropometric variables, age, time between cancer diagnosis and LBM measurement, sex, and race/ethinicity.

To generate sex-by-race/ethnicitiy-specific predictive models, we constructed four different models among sex-by-race/ethnicitiy subgroups: 1) Model 1: height (cm) and weight (kg) only; 2) Model 2: Model 1 plus age, time between cancer diagnosis and LBM measurement date; 3) Model 3: Model 2 plus interaction terms between anthropometric predictors (height $(\mathrm{cm})$ and weight $(\mathrm{kg})$ ) and age; 4) Model 5: Model 3 plus all pairwise interactions between anthropometric variables, age, time between cancer diagnosis and LBM measurement. Beyond height and weight, we also included other anthropometric measures in the models specified above in sensitivity analysis to test whether the inclusion of these other anthropometric variables would yield higher prediction accuracy. Training and testing of algorithms

174 Data were split randomly into 75\%: 25\% for training and testing, respectively. For each imputed dataset, a series of linear regression models with least absolute shrinkage and selection operator (LASSO) penalty for variable selection were fitted, with a bootstrap procedure to obtain confidence intervals and $p$-values ${ }^{40}$. The LASSO was used to develop accurate but parsimonious predictive equations ${ }^{40}$. Results were aggregated across the twenty-five imputed datasets to obtain final coefficient estimates. The combination rule defined by Schomaker et. Al. (2017) was used to combine the bootstrap results across all 25 imputed datasets and construct (95\%) confidence intervals (Cls) that take into 182 account both the variability of variable selection and imputation ${ }^{41}$. To measure model fit, 183 root mean square errors (RMSE) and correlation coefficients $\left(R^{2}\right)$ were calculated on the 184 testing data for the overall sample as well as by sex and race/ethnicity subgroups. The 185 entire training and testing procedure was repeated 10 times and the test set RMSE and $\mathrm{R}^{2}$ was averaged across all 10 replications for each model. 
medRxiv preprint doi: https://doi.org/10.1101/2021.07.05.21259938; this version posted July 7, 2021. The copyright holder for this preprint (which was not certified by peer review) is the author/funder, who has granted medRxiv a license to display the preprint in perpetuity.

All rights reserved. No reuse allowed without permission.

\section{Correlations between predicted biomarkers of muscle mass and LBM}

We tested and compared the strengths of correlations $\left(R^{2}\right)$ between urine creatinine levels and predicted LBM vs that between urine creatinine levels and DXAbased LBM.

\section{RESULTS}

\section{Study Sample Population Characteristics}

The distribution of participant characteristics in the overall study population and by sex are presented in Table 1. We identified 1777 participants with a self-reported cancer diagnosis with a median age of 71 (IQR:60 - 80). There were 933 (52.5\%) females and $844(47.5 \%)$ males. About $23.2 \%$ of the population were of a racial/ethnic minority background: Black ( $\mathrm{n}=218,12.3 \%)$, Mexican American and Hispanic $(\mathrm{n}=162,9.1 \%)$, and Other $(n=33,1.9 \%)$. Men $(55.9 \mathrm{~kg}, S D=9.5)$ had higher DXA-based LBM than women $(41.1 \mathrm{~kg}, \mathrm{SD}=7.4)$. Men were heavier $(83.8 \mathrm{~kg}$ vs. $73.1 \mathrm{~kg})$ and taller than women $(174.3 \mathrm{~cm}$ vs. $160.7 \mathrm{~cm})$.

\section{Algorithm Performance}

Table 2 summarizes the performance of the primary model series overall, by sex, and sex by race stratified models based on $\mathrm{R}^{2}$ and RMSE values. In the overall sample, Model 1 was considered the most parsimonious model with high predictive accuracy $\left(\mathrm{R}^{2}=0.86\right.$ and $\left.\mathrm{RMSE}=4.26\right)$. Also, Model 1 had the best prediction accuracy with the fewest number of predictors (2) among females, $\left(R^{2}=0.93\right.$ and $\left.R M S E=2.46\right)$ and males, $\left(R^{2}=0.94\right.$ and $\left.R M S E=3.39\right)$ and among sex-by-race/ethnicity subgroups.

\section{Algorithms}

Table 3 shows the regression coefficients, of the most parsimonious model to predict DXA-based LBM $(\mathrm{kg})$, overall, by sex and sex-by-race/ethnicity subgroups. Predictors for the overall model consist of weight $(\mathrm{kg})(\beta=0.36$; $\mathrm{p}$-value $<0.001)$ and height (cm) $(\beta=0.52 p$-value<0.05). For females, predictors for the most parsimonious model are weight $(\mathrm{kg})(\beta=0.32 ; \mathrm{p}$-value<0.001) and height $(\mathrm{cm})(\beta=0.17 ; \mathrm{p}$-value=0.15). For males, predictors for the most parsimonious model are weight $(\mathrm{kg})(\beta=0.41$; $\mathrm{p}$-value $<0.001)$, height $(\mathrm{cm})(\beta=0.32$; $\mathrm{p}$-value=0.12). The most parsimonious model for Black, nonHispanic females, White, non-Hispanic females, Mexican-American or Hispanic females, other females, Black, non-Hispanic males, White, non-Hispanic males, Mexican- 
medRxiv preprint doi: https://doi.org/10.1101/2021.07.05.21259938; this version posted July 7, 2021. The copyright holder for this preprint (which was not certified by peer review) is the author/funder, who has granted medRxiv a license to display the preprint in perpetuity.

All rights reserved. No reuse allowed without permission.

218 American or Hispanic males and Other, non-Hispanic males included the same 219 predictors. Similar results were observed when additional anthropometric variables were 220 included to build a series of secondary algorithms.

221 The correlations between urine creatinine levels and LBMs (DXA-based and 222 predicted) are visually represented in Figure 2. The magnitude of correlations between 223 derived LBM-algorithm and urine creatinine levels were large compared to those 224 measured between DXA-based LBM and urine creatinine levels $\left(R^{2}=0.30\right.$ vs. $\left.R^{2}=0.17\right)$ 225 The correlations between predicted LBM measures with urine creatinine levels were 226 comparable to those observed for DXA-based LBM among females $\left(R^{2}=0.25\right.$ vs $\left.R^{2}=0.23\right)$ 227 and among males $\left(R^{2}=0.17\right.$ vs $\left.R^{2}=0.17\right)$. These correlations were similar among sex-by228 race/ethnicity subgroups. Therefore, validating our conclusions that the sex by 229 race/ethnicity stratified Model 1 derived algorithm of LBM $(\mathrm{kg})$ is a sufficient measure for 230 estimating DXA measured LBM $(\mathrm{kg})$.

231 DISCUSSION

232 In this large population-based study, we developed and validated predictive 233 algorithms comprised of simple and routinely measured anthropometric measurements 234 among cancer patients. Sex, race/ethnicity, and time between cancer diagnosis and DXA 235 measurement were also added as predictors to improve accuracy among these 236 subgroups of cancer patients. To the best of our knowledge, there are no previously 237 published data on the derivation of algorithms for predicting LBM among cancer patients 238 using routinely measured anthropometric measurements. The developed algorithms will 239 provide clinicians with a tool to estimate the total LBM composition of cancer patients prior 240 to initiation of chemotherapy based on routinely measured anthropometric measures 241 which are non-invasive and inexpensive.

242 In the non-cancer population, several algorithms to predict body compositions 243 including LBM have been developed and validated ${ }^{23}$, 24. Lee et. al. (2017) recently 244 developed predictive equations using data from NHANES participants (with or without 245 cancer diagnosis) ${ }^{23}$. In this study, a statistical model including age, height, weight, waist 246 circumference, arm circumference, calf circumference, thigh circumference, triceps 247 skinfold, subscapular skinfold, race, accurately predicted LBM in men $\left(R^{2}=0.94\right)$ and 248 women $\left(\mathrm{R}^{2}=0.87\right)^{23}$. In comparison, our most parsimonious model accurately predicted 
medRxiv preprint doi: https://doi.org/10.1101/2021.07.05.21259938; this version posted July 7, 2021. The copyright holder for this preprint (which was not certified by peer review) is the author/funder, who has granted medRxiv a license to display the preprint in perpetuity.

All rights reserved. No reuse allowed without permission.

249 LBM of cancer patients with the same number of features and to a similar degree of fit as

250 Lee et al $(2017)^{23}$. Finally, the predictors of the models were limited to the anthropometric

251 measures collected in NHANES. Published literature supports the use of tricep and

252 subscapular skinfold in conjunction with circumference measures to accurately measure

253 body composition ${ }^{42}$.

\section{Conclusion}

255 Prediction equations utilizing anthropometric predictors of height and weight to 256 estimate DXA-based LBM composition of cancer patients were developed, tested and 257 validated. Models were further improved with sex, race/ethnicity, and time interval 258 between cancer diagnosis and LBM measurement as predictors. These equations will 259 simplify the ability of clinicians to estimate the DXA-based LBM composition of cancer 260 patients prior to initiation of chemotherapy based on routinely measured anthropometric 261 measures which are non-invasive and low cost to patients. Our next step is to apply these 262 derived equations to measure LBM thresholds associated with the risk of chemotherapy 263 adverse events. 
medRxiv preprint doi: https://doi.org/10.1101/2021.07.05.21259938; this version posted July 7, 2021. The copyright holder for this preprint (which was not certified by peer review) is the author/funder, who has granted medRxiv a license to display the preprint in perpetuity.

All rights reserved. No reuse allowed without permission.

\section{REFERENCES}

1. Siegel RL, Miller KD, Jemal A. Cancer statistics, 2020. CA Cancer J Clin. 2020;70(1):7-30.

2. Group. USCSW. U.S. Cancer Statistics Data Visualizations Tool, based on November 2017 submission data (1999-2015): U.S. Department of Health and Human Services, Centers for Disease Control and Prevention and National Cancer Institute. www.cdc.gov/cancer/dataviz. Published June 2018. Accessed June, 2019.

3. Matsuda S, Tsubosa $\mathrm{Y}$, Sato $\mathrm{H}$, et al. Comparison of neoadjuvant chemotherapy versus upfront surgery with or without chemotherapy for patients with clinical stage III esophageal squamous cell carcinoma. Dis Esophagus. 2017;30(2):1-8.

4. Kashiwagi S, Yashiro M, Takashima T, et al. Advantages of adjuvant chemotherapy for patients with triple-negative breast cancer at Stage II: usefulness of prognostic markers E-cadherin and Ki67. Breast Cancer Res. 2011;13(6):R122.

5. Gianni AM, Piccart MJ. Optimising chemotherapy dose density and dose intensity. new strategies to improve outcomes in adjuvant therapy for breast cancer. Eur J Cancer. 2000;36 Suppl 1:S1-3.

6. Prado CM, Baracos VE, McCargar LJ, et al. Body composition as an independent determinant of 5-fluorouracil-based chemotherapy toxicity. Clin Cancer Res. 2007;13(11):3264-3268.

7. Jansman FG, Sleijfer DT, Coenen JL, De Graaf JC, Brouwers JR. Risk factors determining chemotherapeutic toxicity in patients with advanced colorectal cancer. Drug Saf. 2000;23(4):255-278.

8. Roubenoff R, Kehayias JJ. The meaning and measurement of lean body mass. Nutr Rev. 1991;49(6):163-175.

9. Ali R, Baracos VE, Sawyer MB, et al. Lean body mass as an independent determinant of dose-limiting toxicity and neuropathy in patients with colon cancer treated with FOLFOX regimens. Cancer Med. 2016;5(4):607-616.

10. Prado CM, Baracos VE, McCargar LJ, et al. Sarcopenia as a determinant of chemotherapy toxicity and time to tumor progression in metastatic breast cancer patients receiving capecitabine treatment. Clin Cancer Res. 2009;15(8):29202926.

11. Prado CM, Lieffers JR, McCargar LJ, et al. Prevalence and clinical implications of sarcopenic obesity in patients with solid tumours of the respiratory and gastrointestinal tracts: a population-based study. Lancet Oncol. 2008;9(7):629635.

12. Morgan DJ, Bray KM. Lean body mass as a predictor of drug dosage. Implications for drug therapy. Clin Pharmacokinet. 1994;26(4):292-307.

13. Prado CM, Siervo M, Mire E, et al. A population-based approach to define bodycomposition phenotypes. Am J Clin Nutr. 2014;99(6):1369-1377.

14. Flegal KM, Shepherd JA, Looker AC, et al. Comparisons of percentage body fat, body mass index, waist circumference, and waist-stature ratio in adults. $A m \mathrm{~J}$ Clin Nutr. 2009;89(2):500-508. 
medRxiv preprint doi: https://doi.org/10.1101/2021.07.05.21259938; this version posted July 7, 2021. The copyright holder for this preprint (which was not certified by peer review) is the author/funder, who has granted medRxiv a license to display the preprint in perpetuity.

All rights reserved. No reuse allowed without permission.

15. Kouno T, Katsumata N, Mukai H, Ando M, Watanabe T. Standardization of the body surface area (BSA) formula to calculate the dose of anticancer agents in Japan. Jpn J Clin Oncol. 2003;33(6):309-313.

16. Felici A, Verweij J, Sparreboom A. Dosing strategies for anticancer drugs: the good, the bad and body-surface area. Eur J Cancer. 2002;38(13):1677-1684.

17. Baker SD, Verweij J, Rowinsky EK, et al. Role of body surface area in dosing of investigational anticancer agents in adults, 1991-2001. J Natl Cancer Inst. 2002;94(24):1883-1888.

18. Mourtzakis M, Prado CM, Lieffers JR, Reiman T, McCargar LJ, Baracos VE. A practical and precise approach to quantification of body composition in cancer patients using computed tomography images acquired during routine care. Appl Physiol Nutr Metab. 2008;33(5):997-1006.

19. Laskey MA. Dual-energy X-ray absorptiometry and body composition. Nutrition. 1996;12(1):45-51.

20. Bea JW, Zhao Q, Cauley JA, et al. Effect of hormone therapy on lean body mass, falls, and fractures: 6-year results from the Women's Health Initiative hormone trials. Menopause. 2011;18(1):44-52.

21. Kilgour RD, Cardiff K, Rosenthall L, Lucar E, Trutschnigg B, Vigano A. Use of prediction equations to determine the accuracy of whole-body fat and fat-free mass and appendicular skeletal muscle mass measurements from a single abdominal image using computed tomography in advanced cancer patients. Appl Physiol Nutr Metab. 2016;41(1):70-75.

22. Hinton BJ, Fan B, Ng BK, Shepherd JA. Dual energy X-ray absorptiometry body composition reference values of limbs and trunk from NHANES 1999-2004 with additional visualization methods. PLoS One. 2017;12(3):e0174180.

23. Lee DH, Keum N, Hu FB, et al. Development and validation of anthropometric prediction equations for lean body mass, fat mass and percent fat in adults using the National Health and Nutrition Examination Survey (NHANES) 1999-2006. Br J Nutr. 2017;118(10):858-866.

24. Yu S, Visvanathan T, Field J, et al. Lean body mass: the development and validation of prediction equations in healthy adults. BMC Pharmacol Toxicol. 2013;14:53.

25. National Health and Nutrition Examination Surge Overview. (n.d.). Retrieved from https://www.cdc.gov/nchs/data/nhanes/nhanes_13_14/2013-

14_overview_brochure.pdf

26. Johnson CL, Dohrmann SM, Burt VL, Mohadjer LK. National health and nutrition examination survey: sample design, 2011-2014. Vital Health Stat 2. 2014(162):133.

27. Curtin LR, Mohadjer LK, Dohrmann SM, et al. National Health and Nutrition Examination Survey: sample design, 2007-2010. Vital Health Stat 2. 2013(160):1-23.

28. Curtin LR, Mohadjer LK, Dohrmann SM, et al. The National Health and Nutrition Examination Survey: Sample Design, 1999-2006. Vital Health Stat 2. 2012(155):1-39.

29. Institute of Medicine (US) Committee on Nutritional Status During Pregnancy and Lactation. Nutrition During Pregnancy: Part I Weight Gain: Part II Nutrient 
medRxiv preprint doi: https://doi.org/10.1101/2021.07.05.21259938; this version posted July 7, 2021. The copyright holder for this preprint (which was not certified by peer review) is the author/funder, who has granted medRxiv a license to display the preprint in perpetuity.

All rights reserved. No reuse allowed without permission.

Supplements. Washington (DC): National Academies Press (US); 1990. 6, Body Composition Changes During Pregnancy. Available from: https://www.ncbi.nlm.nih.gov/books/NBK235244/

30. Centers for Disease Control and Prevention (CDC). National Center for Health Statistics (NCHS). National Health and Nutrition Examination. Examination Protocol. Hyattsville, MD: U.S. Department of Health and Human Services, Centers for Disease Control and Prevention, 2005-2006 https://wwwn.cdc.gov/nchs/nhanes/search/datapage.aspx?Component=Examinat ion\&CycleBeginYear=2013.

31. Kelly TL, Wilson KE, Heymsfield SB. Dual energy X-Ray absorptiometry body composition reference values from NHANES. PLoS One. 2009;4(9):e7038.

32. Centers for Disease Control and Prevention (CDC). National Center for Health Statistics (NCHS). National Health and Nutrition Examination Survey Technical Documentation for the 1999-2004 Dual Energy X-Ray Absorptiometry (DXA) Multiple Imputation Data files. Hyattsville, MD: U.S. Department of Health and Human Services, Centers for Disease Control and Prevention, 2008 https://wwwn.cdc.gov/Nchs/data/nhanes/dxa/dxa techdoc.pdf

33. Centers for Disease Control and Prevention (CDC). National Center for Health Statistics (NCHS). National Health and Nutrition Examination. Examination Protocol. Hyattsville, MD: U.S. Department of Health and Human Services, Centers for Disease Control and Prevention, 2005-2006 https://wwwn.cdc.gov/nchs/nhanes/search/datapage.aspx?Component=Examinat ion\&CycleBeginYear=2013.

34. Heymsfield SB, Arteaga C, McManus C, Smith J, Moffitt S. Measurement of muscle mass in humans: validity of the 24-hour urinary creatinine method. Am J Clin Nutr. 1983;37(3):478-494.

35. Kim SW, Jung HW, Kim CH, Kim KI, Chin HJ, Lee H. A New Equation to Estimate Muscle Mass from Creatinine and Cystatin C. PLoS One. 2016;11(2):e0148495.

36. Centers for Disease Control and Prevention (CDC). National Center for Health Statistics (NCHS). National Health and Nutrition Examination Laboratory Protocol. Hyattsville, MD: U.S. Department of Health and Human Services, Centers for Disease Control and Prevention, 2013-2014

37. Heeringa S, West BT, Berglund PA. Applied survey data analysis. Second edition. ed. Boca Raton, FL: CRC Press, Taylor \& Francis Group; 2017.

38. van Buuren S, Groothuis-Oudshoorn K. mice: Multivariate Imputation by Chained Equations in R. 2011. 2011;45(3):67.

39. Shah AD, Bartlett JW, Carpenter J, Nicholas O, Hemingway H. Comparison of random forest and parametric imputation models for imputing missing data using MICE: a CALIBER study. Am J Epidemiol. 2014;179(6):764-774.

40. Liu H, Xu X, Li JJ. A Bootstrap Lasso + Partial Ridge Method to Construct Confidence Intervals for Parameters in High-dimensional Sparse Linear Models. 2017:arXiv:1706.02150. https://ui.adsabs.harvard.edu/abs/2017arXiv170602150L. Accessed June 01, 2017. 
medRxiv preprint doi: https://doi.org/10.1101/2021.07.05.21259938; this version posted July 7, 2021. The copyright holder for this preprint (which was not certified by peer review) is the author/funder, who has granted medRxiv a license to display the preprint in perpetuity.

All rights reserved. No reuse allowed without permission.

41. Schomaker M, Heumann C. Bootstrap inference when using multiple imputation. Statistics in Medicine. 2018;37(14):2252-2266.

42. Harris TB, Visser M, Everhart $J$, et al. Waist circumference and sagittal diameter reflect total body fat better than visceral fat in older men and women. The Health, Aging and Body Composition Study. Ann N Y Acad Sci. 2000;904:462-473. 
medRxiv preprint doi: https://doi.org/10.1101/2021.07.05.21259938; this version posted July 7, 2021. The copyright holder for this preprint (which was not certified by peer review) is the author/funder, who has granted medRxiv a license to display the preprint in perpetuity.

All rights reserved. No reuse allowed without permission.

Figure 1. Flow chart describing the development, training, and validation samples for analysis from 8 NHANES cycles 1999-2014

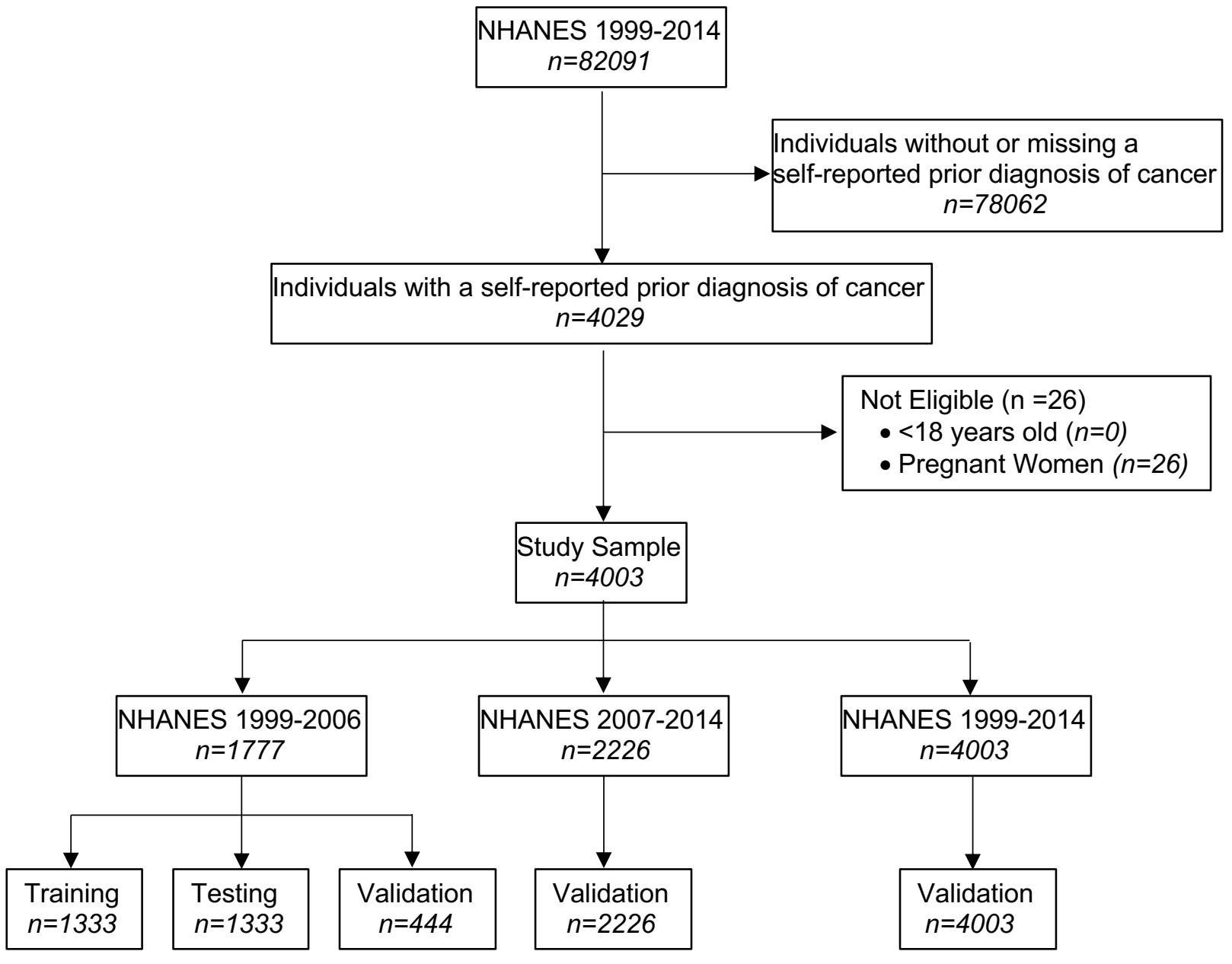


medRxiv preprint doi: https://doi.org/10.1101/2021.07.05.21259938; this version posted July 7, 2021. The copyright holder for this preprint (which was not certified by peer review) is the author/funder, who has granted medRxiv a license to display the preprint in perpetuity. All rights reserved. No reuse allowed without permission.

Table 1. Distribution of baseline characteristics between men and women with at least one selfreported prior diagnosis of cancer, NHANES Survey Cycles 1999-2006

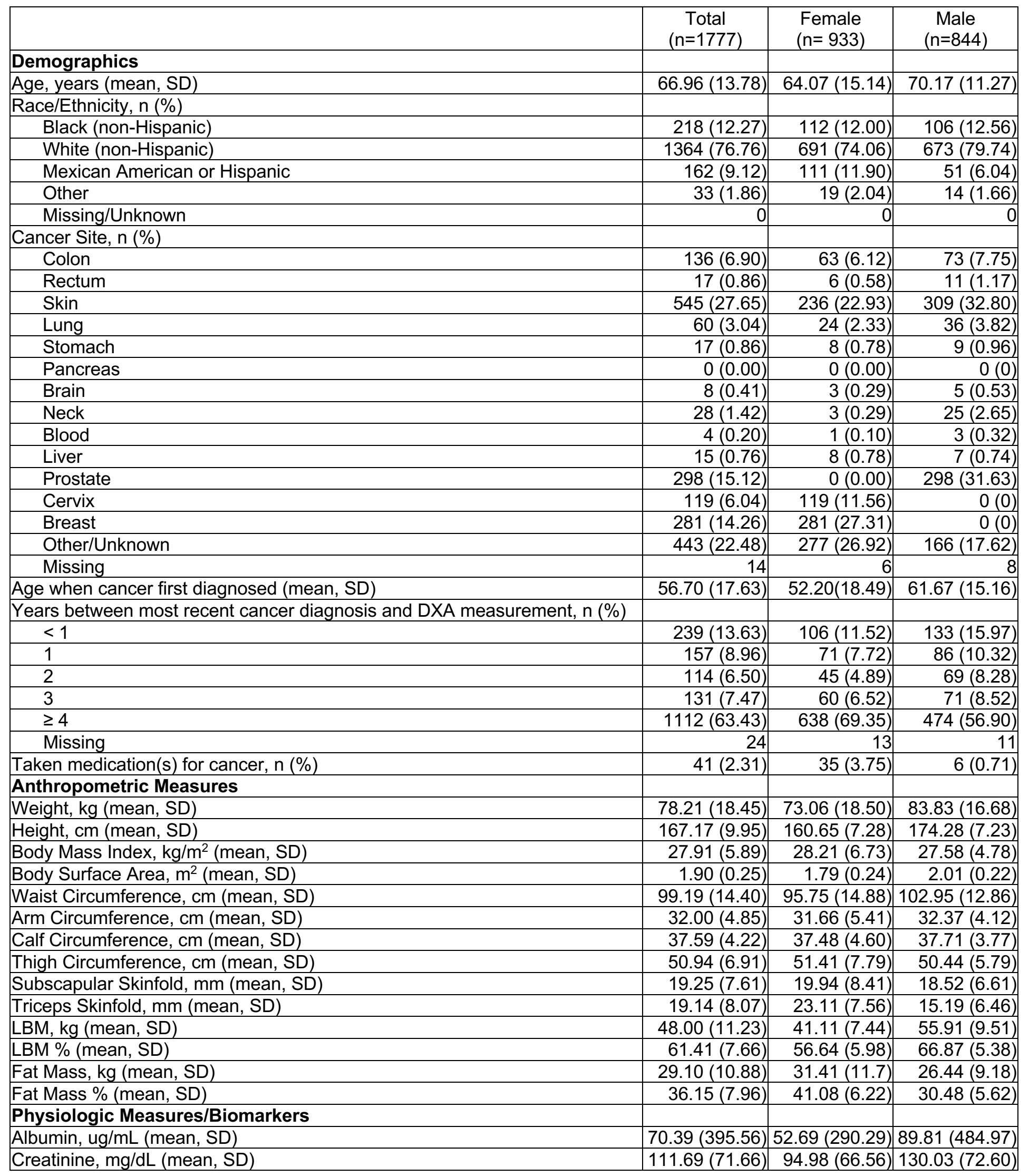


medRxiv preprint doi: https://doi.org/10.1101/2021.07.05.21259938; this version posted July 7, 2021. The copyright holder for this preprint (which was not certified by peer review) is the author/funder, who has granted medRxiv a license to display the preprint in perpetuity.

All rights reserved. No reuse allowed without permission.

Table 2. Measures of model fit for primary anthropometric prediction equations for total LBM.

\begin{tabular}{|c|c|c|c|c|c|c|c|c|c|c|}
\hline & \multicolumn{2}{|c|}{ Model 1* } & \multicolumn{2}{|c|}{ Model $2^{\S}$} & \multicolumn{2}{|c|}{ Model $3^{+}$} & \multicolumn{2}{|c|}{ Model $4^{\dagger}$} & \multicolumn{2}{|c|}{ Model $5^{\ddagger}$} \\
\hline & RMSE $^{++}$ & $\mathrm{R}^{2 \dagger \dagger}$ & $\mathrm{RMSE}^{++}$ & $R^{2 \dagger \dagger}$ & $\mathrm{RMSE}^{++}$ & $\mathrm{R}^{2 \dagger \dagger}$ & $\mathrm{RMSE}^{++}$ & $\mathrm{R}^{2 \dagger \dagger}$ & $\mathrm{RMSE}^{++}$ & $\mathrm{R}^{2+\dagger}$ \\
\hline All & 4.26 & 0.86 & 2.99 & 0.93 & 2.81 & 0.94 & 2.81 & 0.94 & 2.86 & 0.94 \\
\hline All Females & 2.64 & 0.93 & 2.59 & 0.93 & 2.61 & 0.93 & 2.61 & 0.93 & 2.61 & 0.93 \\
\hline Black & 3.78 & 0.77 & 3.84 & 0.76 & 4.31 & 0.69 & & & 3.85 & 0.76 \\
\hline White & 2.54 & 0.93 & 2.49 & 0.93 & 2.55 & 0.93 & & & 2.52 & 0.93 \\
\hline $\begin{array}{l}\text { Mexican-American or } \\
\text { Hispanic }\end{array}$ & 2.26 & 0.95 & 2.57 & 0.93 & 2.90 & 0.92 & & & 2.56 & 0.93 \\
\hline Other & 3.66 & 0.83 & 3.95 & 0.81 & 4.96 & 0.67 & & & 3.81 & 0.83 \\
\hline All Males & 3.39 & 0.94 & 3.13 & 0.95 & 3.20 & 0.95 & 3.20 & 0.95 & 3.23 & 0.95 \\
\hline Black & 3.59 & 0.94 & 3.21 & 0.95 & 3.81 & 0.93 & & & 3.2 & 0.95 \\
\hline White & 3.44 & 0.94 & 3.17 & 0.95 & 3.21 & 0.95 & & & 3.24 & 0.95 \\
\hline $\begin{array}{l}\text { Mexican-American } \\
\text { Hispanic }\end{array}$ & 3.72 & 0.88 & 3.63 & 0.89 & 4.61 & 0.82 & & & 3.45 & 0.90 \\
\hline Other & 3.95 & 0.83 & 4.43 & 0.79 & 8.58 & 0.24 & & & 4.00 & 080 \\
\hline
\end{tabular}

${ }^{*}$ Model 1 predictors are height $(\mathrm{cm})$ and weight $(\mathrm{kg})$ only.

$\S$ Model 2 predictors are height $(\mathrm{cm})$, weight $(\mathrm{kg})$ and age.

+ Model 3 predictors are Model 2 predictors plus time interval between cancer diagnosis and DXA scan, sex, race/ethnicity.

† Model 4 predictors consist of Model 3 predictors plus additional interaction terms between anthropometric variables and race/ethnicity.

‡ Model 5 predictors are Model 4 predictors plus all pairwise interactions between anthropometric variables, age, time interval between cancer diagnosis and DXA scan, sex, and race/ethnicity.

${ }^{++}$RMSE $=$Root Mean Square Error

${ }^{\dagger \dagger} R^{2}=R$-squared 
medRxiv preprint doi: https://doi.org/10.1101/2021.07.05.21259938; this version posted July 7, 2021. The copyright holder for this preprint (which was not certified by peer review) is the author/funder, who has granted medRxiv a license to display the preprint in perpetuity.

All rights reserved. No reuse allowed without permission.

Table 3. Regression coefficients for the most parsimonious models overall, by sex, and by sex and race/ethnicity of the associations between anthropometric measures and total LBM.

\begin{tabular}{|l|l|}
\hline \multicolumn{1}{|c|}{ Categories } & \multicolumn{1}{c|}{ Algorithms } \\
\hline All & $L B M=-67.74+0.36^{\ddagger} *($ Weight $)+0.52^{\dagger} *($ Height $)$ \\
\hline All Females & $L B M=-10.64+0.32^{\ddagger} *($ Weight $)+0.17 *($ Height $)$ \\
\hline Black & $L B M=1.23+0.31 *($ Weight $)+0.12 *($ Height $)$ \\
\hline White & $L B M=-9.37+0.32^{\ddagger} *($ Weight $)+0.17 *($ Height $)$ \\
\hline $\begin{array}{l}\text { Mexican- } \\
\text { American or } \\
\text { Hispanic }\end{array}$ & $L B M=-13.25+0.34^{\S} *($ Weight $)+0.18 *($ Height $)$ \\
\hline Other & $L B M=-37.29+0.35^{\dagger} *($ Weight $)+0.33 *($ Height $)$ \\
\hline All Males & $L B M=-33.46+0.41^{\ddagger} *($ Weight $)+0.32 *($ Height $)$ \\
\hline Black & $L B M=-31.05+0.46^{\ddagger} *($ Weight $)+0.29 *($ Height $)$ \\
\hline White & $L B M=-33.45+0.41^{\ddagger} *($ Weight $)+0.32 *($ Height $)$ \\
\hline $\begin{array}{l}\text { Mexican- } \\
\text { American or } \\
\text { Hispanic }\end{array}$ & $L B M=-34.38+0.43^{\dagger} *($ Weight $)+0.32 *($ Height $)$ \\
\hline Other & $L B M=-58.82+0.36^{\dagger} *($ Weight $)+0.49 *($ Height $)$ \\
\hline
\end{tabular}

$\ddagger \mathrm{P}$-value $\leq 0.001$

$\S$ P-value $\leq 0.01$

† P-value $\leq 0.05$ 
medRxiv preprint doi: https://doi.org/10.1101/2021.07.05.21259938; this version posted July 7, 2021. The copyright holder for this preprint (which was not certified by peer review) is the author/funder, who has granted medRxiv a license to display the preprint in perpetuity. All rights reserved. No reuse allowed without permission.

Figure 3. Correlations between serum creatinine levels ( $\mathrm{mg} / \mathrm{dL})$ with DXA-based LBM $(\mathrm{kg})$ and derived LBM-algorithm $(\mathrm{kg})$ in the overall sample and by sex and race/ethnicity subgroups.

All
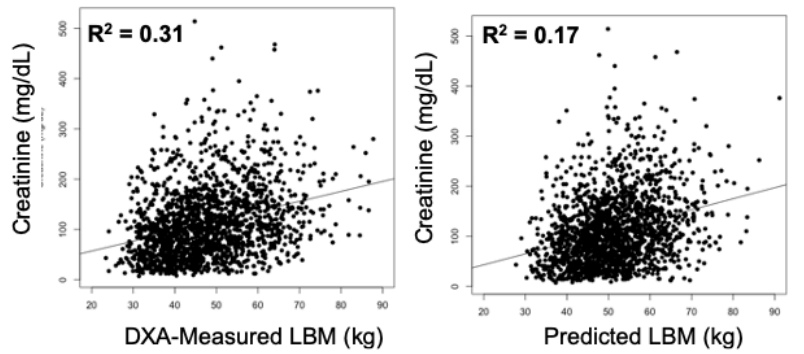

All Females
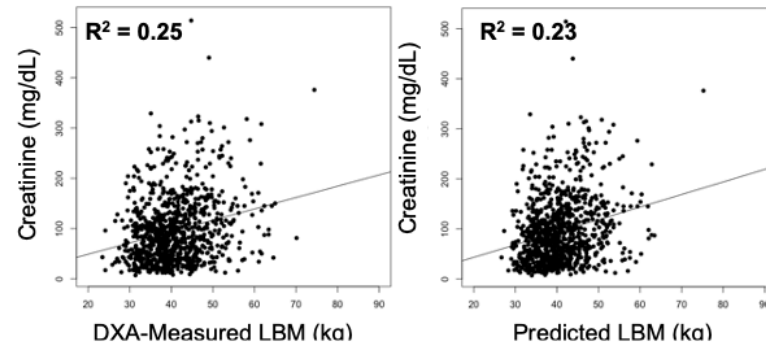

Black Females
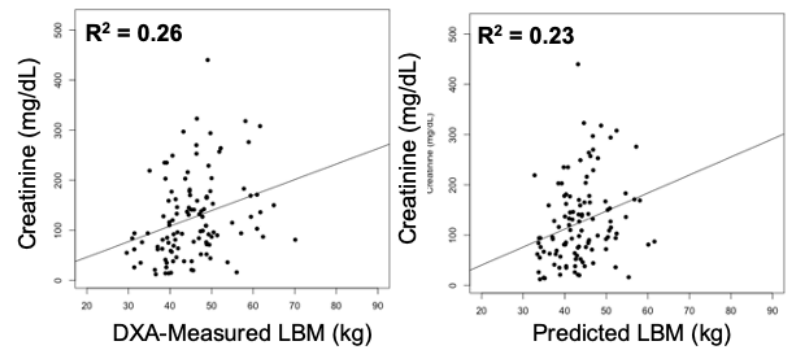

White Females
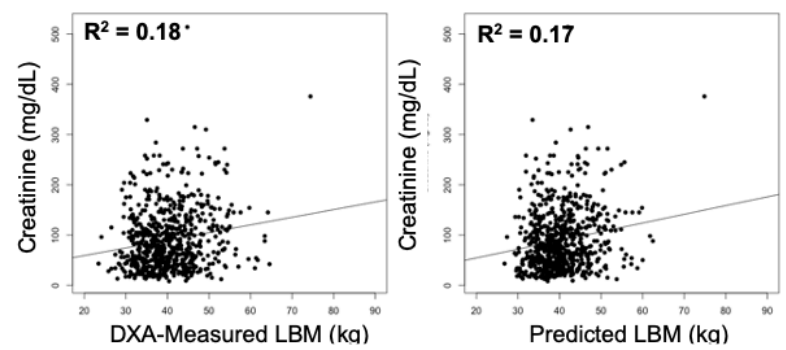

Mexican-American and Hispanic Females
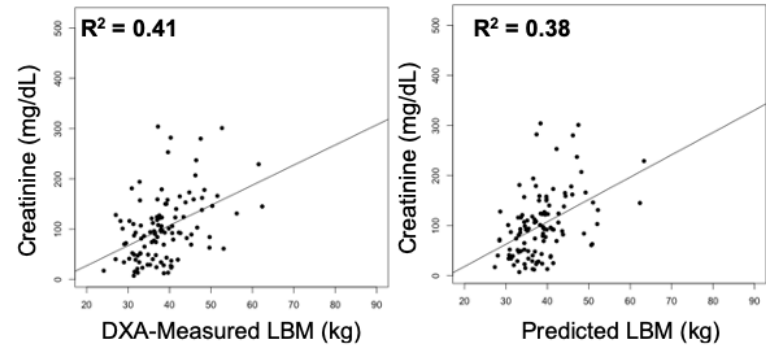

Other Females
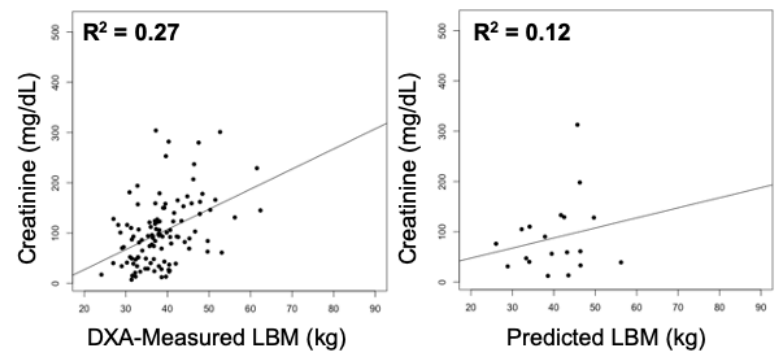

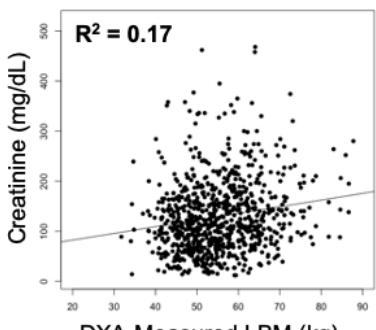

DXA-Measured LBM (ka)

Black Males
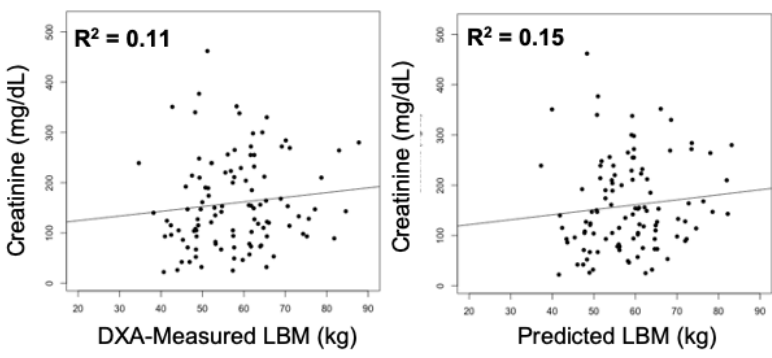

White Males
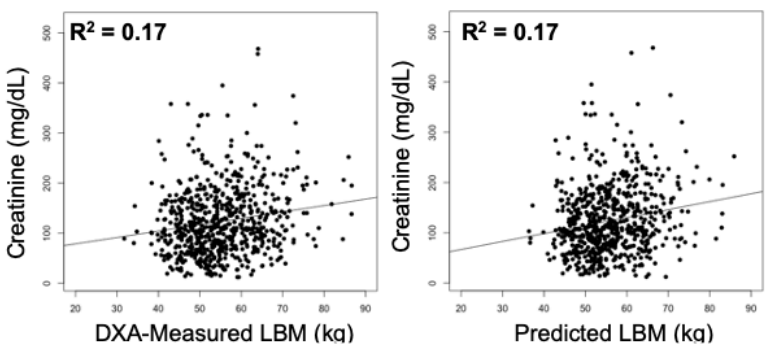

Mexican-American and Hispanic Males
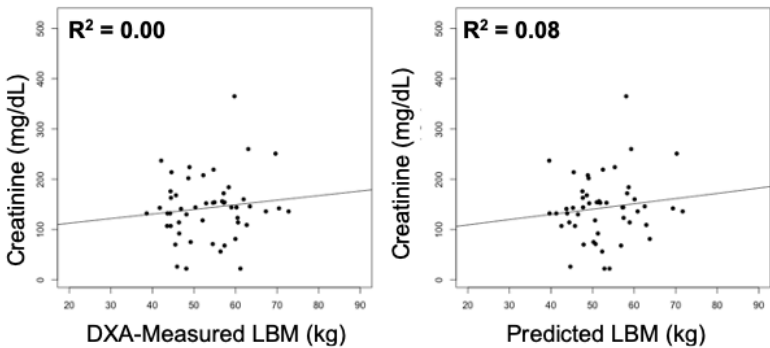

Other Males
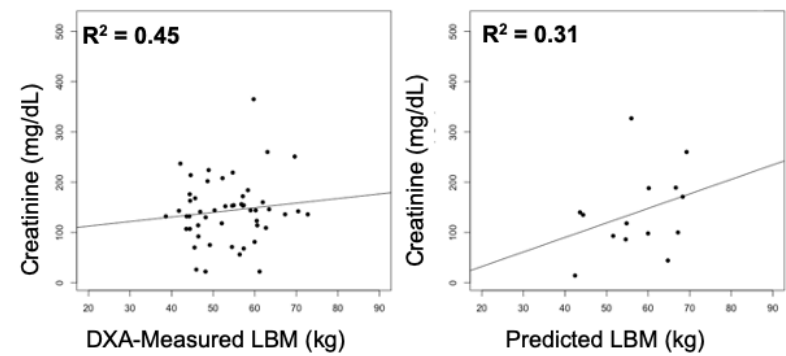